\title{
Some aspects of disease management of cherry leaf spot (Blumeriella jaapii) with special reference to pesticide use
}

\author{
Holb, I. J., Lakatos, P. \& Abonyi, F. \\ Centre for Agricultural Sciences and Engineering, University of Debrecen 138 Böszörményi St., \\ 4032 Debrecen, Hungary
}

\begin{abstract}
Summary: In this review, some aspects of disease management of cherry leaf spot (Blumeriella jaapii) are summarised with special reference to pesticide use. In the first part of the review, we show the non-chemical control approach (e. g. removal of fallen leaves, planting resistant cultivar) against leaf spot. In the second part of the review, the effect of pesticides including fertilizers (urea) and fungicides on cherry leaf spot are discussed. Special attention are given to the fungicides of copper, dodine, captafol, captan, benomil, chlorothalonil, sterol demethylation inhibitors (e.g. fenarimol, fenbuconazole, myclobutanil, tebuconazole), and strobilurins about their effectiveness against cherry leaf spot. In the final part of the review, possibilities of cherry leaf spot control are discussed in integrated and organic cherry orchards.
\end{abstract}

Key words: Blumeriella jaapii, cherry leaf spot, disease control, fungicides, non-chemical approach, urea, copper, captan, chlorothalonil, dodine, DMI, strobilurins

\section{Introduction}

Cherry leaf spot, caused by the fungus Blumeriella jaapii (Rehm) Arx, is a widely-spread disease in most sour and sweet cherry growing areas all over the world. Under humid climate, the disease causes severe leaf defoliation in the second half of the season. Cherry leaf spot significantly reduces profits for sour cherry growers in Hungary in every humid year (Kaszonyi, 1955, 1966; Glits, 1962; Benedek et al., 1990; Pedersen \& Lrschenkohl, 1997; Holb, 2002; Jenser \& Véghelyi, 2003; Holb \& Veisz, 2005; Király \& Szentpéteri, 2006; Nyéki et al., 2008). Cherry leaf spot causes defoliation by midsummer, which results in soft, poorly colored fruit that are low in soluble solids. Early defoliation delays acclimation of fruit buds and wood to cold temperatures in the fall, increases tree mortality during severe winters, and reduces fruit bud survival and fruit set the following year (Kaszonyi, 1966; Howell \& Stackhouse, 1973; Jenser \& Véghelyi, 2003; Holb \& Veisz, 2005; Holb, 2009).

A combination of biological, economic, and regulatory factors puts sour cherry industry in a precarious position regarding disease management. First, the sour cherry cultivar (Érdi bőtermő, Újfehértói fürtös, Debreceni bőtermő) which comprises nearly $90 \%$ of sour cherry production in Hungary, is highly susceptible to cherry leaf spot. Sources of resistance have been identified all over the world (e.g. Sjulin et al., 1989; Hrotkó, 1997; Downey, 1999; Apostol, 2000; Wharton et al., 2003; Rozsnyai \& Apostol, 2005; Schuster \& Wolfram, 2005), but resistance has not been incorporated into cultivars that meet the needs of producers. Managing leaf spot in
Hungary typically requires five to seven fungicide applications per year, starting at about the time of petal fall and continuing until leaf fall (Jenser \& Véghelyi, 2003; Holb \& Veisz, 2005).

The aim of this review was to summarize some aspects of disease management of cherry leaf spot (Blumeriella jaapii) with special reference to pesticide (fertilizer and fungicide) use.

\section{Non-chemical control approach against cherry leaf spot}

In early studies (Keitt, 1918; Keitt et al., 1937), removal of fallen, infected leaves in autumn are recommended for reducing disease incidence in the following year (Table 1). In small orchards, raking up the fallen, infected leaves, while in large orchards, leaf collectors can be used for leaf collection. Collected leaves need to be destroyed in order to avoid overwintering and spore production of the pathogen on infected fallen leaves.

Other way of cultural practices is to plant leaf spot resistant cultivars (Table 1). However, no highly resistant cultivars to leaf spot are available for sweet cherry cultivars (Holb, 2009). Therefore, the only way is to plant less susceptible or tolerant sweet cherry cultivars. Sour cherry cultivars 'Csengődi' and 'Akasztói' are known to be resistant to leaf spot (Apostol et al., 2000; Rozsnyai \& Apostol, 2005) which are recommended for planting in organic cherry production. 


\section{Chemical control of cherry leaf spot}

\section{Synthetic fertilizers}

Nitrogen fertilisers (i.e. urea) are recommended to reduce overwintering inoculum sources of cherry leaf spot (Table 1) (e. g. Holb, 2002; Jenser \& Véghelyi, 2003; Holb \& Veisz, 2005). Pedersen \& Hockenhull (1996), Bengtsson et al. (2006) and Green et al. (2006) demonstrated that the use of urea applied at leaf fall can be an alternative approach to reduce the amount of primary inoculum produced by the pathogen in the spring. This method has also been investigated for the control of apple scab (e. g. MacHardy, 1996; Holb et al, 2006). Bengtsson et al. (2006) demonstrated that the use of urea as a post leaf fall application in integrated disease management would seem to be a very promising method for reducing the primary inoculum of the cherry leaf spot pathogen; however, the results of the study show the importance of careful timing of urea application. Thus application must be made when the fungus is in its active saprotrophic growth phase, and there is thus a window for successful control by this method of approximately four weeks after leaf fall. Green et al. (2006) found clear differential effects of urea application to cherry leaf litter and urea reduced leaf spot incidence in the following spring. The reason for pathogen reduction could be a combination of factors including: (i) ammonia toxicity, (ii) increase in $\mathrm{pH}$ and (iii) antagonism/competition from microorganisms, which are favoured by urea application. These three factors together adversely affected the saprotrophic growth of $B$. jaapii, leading to reduced production of ascospores and winter-conidia the following spring.

\section{Synthetic fungicides}

In order to avoid severe infection, fungicide control programmes are initiated from petal fall stage of blossom and continued on a 7-10-day schedule (Table 1). Five to seven fungicide applications per season can control effectively the disease (e. g. Jenser \& Véghelyi, 2003; Holb \& Veisz, 2005). Fungicides are recommended to apply at petal fall, shuck fall, and 2 and 6 weeks later as well as postharvest applications are helpful in wet years (e. g. Jenser \& Véghelyi, 2003; Holb \& Veisz, 2005). Rotating or tank-mixing fungicides are reccommended to prevent resistant strains of $B$. jaapii from developing. High risk of resistance development can be for DMI-type and QoI fungicides.

The most important fungicides against cherry leaf spot are copper, dodine, captafol, captan, benomyl, chlorothalonil, sterol demethylation inhibitors (DMIs) including fenarimol, fenbuconazole, myclobutanil, and tebuconazole, and the QoI class of respiration inhibitor fungicides (Table 1 ).

The use of Bordeaux mixture (copper sulfate plus hydrated lime) for the control of cherry leaf spot and other diseases of cherry dates to the late 1800s (reviewed in Keitt et al. 1937). Two decades research of Keitt et al. (1937) showed that although Bordeaux mixture was phytotoxic to sour cherry leaves and reduced fruit size slightly, its efficacy in controlling cherry leaf spot far outweighed the negative side effects. Nevertheless, the use of Bordeaux on sour cherry diminished with the introduction of synthetic fungicides (e.g. dodine, captan, captafol) in the 1940s and 1950s (Jones et al., 1993). Because the mode of action of copper is nonspecific denaturation of proteins (Ware \& Whitacre, 2004), fungi are not likely to become resistant to it.

From 1950s, dodine was used to control the disease in Michigan before it was replaced by captafol (reviewd in Jones et al., 1993). From the end 1960s until the end of 1980s, captafol was the predominant fungicide used in spray programs for leaf spot bacuse it gave consistently good control when applied on a 14-day interval. Since the loss of captafol, growers have not returned to dodine bacuse of concenrns about dodine-resistant strains of B. jaapii after many years of dodine usage in many countries. Benomyl was effective for leaf spot control until the pathogen developed resistance to it and related compounds (Holmstrup et al., 1998). Benomyl was also used in late autumn applications to

Table 1. Some features of disease management of cherry leaf spot in cherry orchards with non-chemical control approach, fertilisers and fungicides

\begin{tabular}{|c|c|c|c|}
\hline & Non-chemical control & Fertilisers & Fungicides \\
\hline $\begin{array}{l}\text { Method } \\
\text { or } \\
\text { material }\end{array}$ & $\begin{array}{l}\text { removal of fallen } \\
\text { leaves, } \\
\text { planting resistant } \\
\text { cultivar } \\
\text { leaf fall }\end{array}$ & nitrogen fertiliser (urea) & $\begin{array}{l}\text { copper, dodine, captafol, captan, benomyl, } \\
\text { chlorothalonil, sterol demethylation } \\
\text { inhibitors (DMIs) including fenarimol, } \\
\text { fenbuconazole, myclobutanil, and } \\
\text { tebuconazole, and the QoI class of } \\
\text { respiration inhibitor fungicides } \\
\text { leaf fall (benomyl) } \\
\text { season long application }\end{array}$ \\
\hline Reference & $\begin{array}{l}\text { e. g. Keitt, 1918; Keitt } \\
\text { et al., 1937; Apostol et } \\
\text { al., 2000; Rozsnyai \& } \\
\text { Apostol, 2005; Holb, } \\
2009\end{array}$ & $\begin{array}{l}\text { e. g. Pedersen \& } \\
\text { Hockenhull, 1996; Holb, } \\
\text { 2002; Jenser \& Véghelyi, } \\
\text { 2003; Bengtsson et al., } \\
\text { 2006; Green et al., } 2006\end{array}$ & $\begin{array}{l}\text { e. g. Keitt et al. 1937; Jones et al., 1993; } \\
\text { Howell \& Stackhouse, 1973; Eisensmith et } \\
\text { al., 1981; Jones, 1995; McManus \& } \\
\text { Weidman, 2001; Holb, 2002; Jenser \& } \\
\text { Véghelyi, 2003; Sundin et al., 2004, 2005; } \\
\text { Holb \& Veisz, 2005; Pfoffer et al., 2006; Ma } \\
\text { et al., 2006; McManus et al., 2003, 2007 }\end{array}$ \\
\hline
\end{tabular}


reduce inoculum development on fallen, infected leaves. After the late 1980s, chlorothalonil has replaced captafol for leaf spot control form petal fall to shuck split. However, label restriction do not allow midsummer applications of cholothalonil. Because of residue concerns, chlorothalonil may not be applied after the phenological stage known as "shuck split," which occurs about 1 week after petal fall, although it may be used again after harvest (McManus et al., 2007). Chlorothalonil and captan classified as B2 carcinogens (by the U.S. Environmental Protection Agency), therefore, their uses are restricted or banned on major crops and registrants are forced to cut their uses on relatively minor crops, such as sour cherry, in order to retain more profitable uses.

The DMI fungicides have exhibited ecellent activity against the leaf spot fungus (Howell \& Stackhouse, 1973; Eisensmith et al., 1981; Jones, 1995; McManus \& Weidman, 2001). Jones et al. (1993) showed that DMI fungicides could be used to control leaf spot in summer between shuck split and harvest or season-long programs starting at petal fall. Because DMI fungicides may be used season long, and are active against brown rot and powdery mildew as well as cherry leaf spot (Jones et al., 1993; McManus \& Weidman, 2001; Sundin et al., 2004), they have been used intensively in season-long disease control programs. The intensive use of the DMI fungicides exerts selective pressure favoring fungicide-resistant strains of $B$. jaapii. Reports from the United States suggest that the efficacy of DMI fungicides to control cherry leaf spot declined from the late 1980s when they were first introduced (Jones et al., 1993; McManus \& Weidman, 2001; Jones et al., 2003; Sundin et al., 2005). Proffer et al. (2006) in laboratory assays showed that some $B$. jaapii isolates from sites where DMI fungicides had been used intensively were not inhibited at DMI fungicide concentrations 100 times greater than the concentration that inhibited sensitive isolates. Pfoffer et al. (2006) showed that an orchard (Benzie County, MI, USA) had suffered catastrophic tree losses due to winter injury after the 2002 season, when fenbuconazole failed to control cherry leaf spot and trees in the orchard were defoliated early in the summer. Results of the field study of Pfoffer et al. (2006) confirmed that (i) the efficacy of DMI fungicides in controlling cherry leaf spot has decreased over the years since their introduction, (ii) cross-resistance to four DMI fungicides (fenbuconazole, tebuconazole, myclobutanil, and fenarimol) exists in populations of $B$. jaapii, and (iii) the frequency of isolates with resistance to DMIs is higher in commercial orchards with a history of DMI use than in unsprayed trees. Related to this study, $M a$ et al. (2006) determined that the overexpression of CYP51 conferred DMI resistance in $B$. jaapii and that this phenotype was strongly correlated with the presence of a truncated transposable element upstream of CYP51. This result raises the possibility that the overexpression of CYP51 in DMI reisitant isolates may impose deleterious effects on the fitness of the DMI reisitant isolates in orchards without DMI selection pressure. Thus, the frequency of resistant isolates in the pathogen population may decline after growers cease using DMIs or use them in combination or alternation with other fungicides. Authors suggested that alternatives to DMI fungicides for cherry leaf spot control can be strobilurins and copper compounds.

QoI class of respiration inhibitor fungicides, such as pyraclostrobin and trifloxystrobin were registered on sour cherry. Pyraclostrobin is also packaged with boscalid, a respiration inhibitor with a mode of action different from that of the QoI fungicides. Boscalid, pyraclostrobin, and trifloxystrobin have been labelled as "reduced risk" by EPA, based on their low toxicity to mammals. In field trials (Jones \& Ehret, 2000; McManus \& Weidman, 2001; McManus et al., 2003), the QoI fungicides have proven effective against cherry leaf spot, brown rot, and powdery mildew. However, the QoI fungicides are prone to fungicide resistance such as DMI fungicides (Gisi et al., 2003). Therefore, it is critical to develop cherry leaf spot management programs that exploit the strengths of the DMI and QoI fungicides but that are not entirely reliant on them. McManus et al. (2007) showed that most copper-based fungicides are less expensive than DMIs, QoIs, or chlorothalonil, but are as convenient to use as synthetic fungicides. These features make copper an obvious option for cherry leaf spot control in cherry orchards.

McManus et al. (2007) showed that spray programs in which chlorothalonil was applied during the bloom through shuck-split stage followed by copper-based fungicides in early cover sprays were highly effective in controlling cherry leaf spot. DMI and respiration inhibitor fungicides are effective against brown rot and powdery mildew (Jones \& Ehret, 2000; McManus \& Weidman, 2001; McManus et al., 2003; Sundin et al., 2005), and these fungicides were applied in fourth and fifth cover sprays to protect fruit from brown rot just prior to harvest. McManus et al. (2007) also monitored the compatibility of copper-based fungicides with various insecticides, and lime was also added to some treatments in order to mitigate the phytotoxicity associated with copperbased fungicides.

Pesticides of dinitro ortho cresole (DNOC) and benomil were also recommended to use as an autumn application to fallen leaves in order to reduce inoculum production in the follwing spring (Anderson, 1956). However, these pesticides were banned in the last decades due to environmental and toxicity issues, therefore, they are not allowed to use anymore against cherry leaf spot.

\section{Cherry leaf spot control in integrated and organic cherry orchards}

In integrated fruit production, growers can use only those fungicides which are sorted into 'green' and 'yellow' list of active ingredients by the international and domestic integrated fruit production guidelines. Another criterium is the use of disease warning system in order to time fungicide applications and reduce the number of sprays in the seasonlong spray programs. Cherry leaf spot forecasting was developed in the early 1980s by Eisensmith \& Jones (1981) 
and Eisensmith et al. (1982a,b). The warning system was successfully implemented in the practice and used in integrated cherry production in many cherry growing regions in the United States. For instance, PennState University has been given leaf spot forecasting for several years according to the study of Eisensmith \& Jones (1981). Their disease warning system indicates low, moderate and severe risk of infection by spores of $B$. jaapii during the whole growing season in order to help fungicide timing of their cherry growers.

For organic cherry production, removal of fallen, infected leaves in autumn can be recommended for reducing leaf spot incidence in the following year. In small orchards, raking up the fallen, infected leaves, while in large orchards, leaf collectors can be used for leaf collection (Holb \& Veisz, 2005). Collected leaves need to be destroyed in order to avoid overwintering and spore production of the pathogen on infected fallen leaves. Other way of cultural practices is to plant leaf spot resistant cultivars though the use of this option is very limited due to only few sour cherry cultivars ('Csengődi' and 'Akasztói') resistant to leaf spot (Apostol et al., 2000; Rozsnyai \& Apostol, 2005). In organic fruit production, the chemical control options are limited and there is a high infection risk by spores of B. jaapii. Copper is the only effective compound against the disease which can be used safely only at the begining and at the end of the season against cherry leaf spot (Holb \& Veisz, 2005).

\section{Acknowledgements}

The study was supported by the NKTH programme (OM00227/2008) and by the research programme of OTKA (K 78399) as well as by a János Bolyai Research Fellowship.

\section{References}

Anderson (1956): Diseases of fruit crops. McGraw-Hill, New York, $501 \mathrm{p}$.

Apostol, J. (2000): Hungarian resistance breeding in sour cherries. Acta Horticulturae, 538: 363-365.

Benedek, P., Nyéki, J. \& Vályi, I. (1990): Csonthéjas gyümölcsfajták érzékenysége a fontosabb kórokozókkal és kártevőkkel szemben - A fajtaspecifikus növényvédelmi technológia kidolgozása. Növényvédelem 26 (1): 12-31.

Bengtsson M., Hockenhull, J. \& de Neergaard, E. (2006): Histopathological study of the effect of post leaf fall application of urea on saprotrophic development of the cherry leaf spot pathogen, Blumeriella jaapii. Journal of Plant Diseases and Protection, 113 (5): 214-218.

Downey, S. (1999): Genetic diversity of Prunus serotina and the evaluation of other wild species for breeding sour cherry resistant to cherry leaf spot. M.Sc. thesis. Michigan State University, East Lansing

Eisensmith, S. P., \& Jones, A. L. (1981): Infection model for timing of fungicide applications to control cherry leaf spot. Plant Disease, 65: 955-958.
Eisensmith, S. P., Jones, A. L. \& Cress, C. E. (1982a): Effects of interrupted wet periods on infection of sour cherry by Coccmyces hiemalis. Phytopathology, 72: 680-682.

Eisensmith, S. P., Sjulin, T. M., Jones, A. L. \& Cress, C. E. (1982b): Effects of age and inculum conentration on infection of sour cherry by Coccmyces hiemalis. Phytopathology, 72: 574-577.

Gisi, U., Chin, K. M., Knapova, G., Farber, R.K., Mohr, U., Parisi, S., Sierotzki, H. \& Steinfeld, U. (2000): Recent developments in elucidating modes of resistance to phenylamide, DMI, and strobilurin fungicides. Crop Protection, 19: 836-872.

Glits, M. (1962): A cilindrospóriumos betegség hazai előfordulása termőfákon. Kertészet és Szőlészet, 24: 18-19.

Green, H., Bengtsson, M., Duval, X., Pedersen, H. L., Hockenhull, J. \& Laresen, J. (2006): Influence of urea on the cherry leaf spot pathogen, Blumeriella jaapii, and on microorganisms in decomposing cherry leaves. Soil Biology and Biochemistry, 38: 2731-2742.

Holb, I. (2002): Blumeriellás levélfoltosság. 173-175. (In: Radócz, L. (ed.): A héjasok növényvédelme.) Szaktudás Kiadóház, Budapest, pp. 256.

Holb, I. (2009): Some biological features of cherry leaf spot (Blumeriella jaapii) with special reference to cultivar susceptibility International Journal of Horticultural Science, 15 (1-2): 91-94.

Holb I. \& Veisz, J. (2005): A cseresznye és a meggy jelentősebb kórokozói. 138-144. (In: Holb I. (ed.): A gyümölcsösök és a szőlő ökológiai növényvédelme.) Mezőgazda Kiadó, Budapest, pp. 341.

Howell, G. S., \& Stackhouse, S. S. (1973): The effect of defoliation time on acclimation and dehardening in tart cherry (Prunus cerasus L.). Journal of the American Society for Horticultural Sciences, 98: 132-136.

Hrotkó, K. (1997): Alanyfajták. p. 134-159. (In: Soltész M. (ed.): Integrált gyümölcstermesztés.) Mezőgazda Kiadó, Budapest

Jenser, G. \& Véghelyi, K. (2003): A cseresznye és a meggy növényvédelme. pp. 259-295. In: Hrotkó K. (szerk.) Cseresznye és meggy. Mezőgazda Kiadó, Budapest, p. 419.

Jones, A. L. (1995): Cherry leaf spot. Pages 21-22 in: Compendium of Stone Fruit Diseases. J. M. Ogawa, E. I. Zehr, G. W. Bird, D. F. Ritchie, K. Uriu, and J. K. Uyemoto, eds. American Phytopathological Society, St. Paul, MN.

Jones, A. L. \& Ehret, G. R. (2000): Evaluation of strobilurin fungicides for cherry leaf spot and brown rot control, 1999. Fungicide and Nematicide Tests 55:53. The American Phytopathological Society, St. Paul, MN.

Jones, A. L., Ehret, G. R., Garcia, S. M., Kesner, C. D. \& Klein, W. M. (1993): Control of cherry leaf spot and powdery mildew on sour cherry with alternate-side applications of fenarimol, myclobutanil, and tebuconazole. Plant Disease, 77: 703-706.

Jones, A. L., Ehret, G. R., Sundin, G. W., Nugent, J. E., \& Klein, W. M. (2003): New fungicide evaluation on Montmorency tart cherries for leaf spot control, 2002. Fungicide and Nematicide Tests 58: STF003.

Kaszonyi, S. (1955): Faiskolai csonthéjasok cylindrospóriumos betegsége. Növénytermelés, 4: 337-350.

Kaszonyi, S. 1966: Life cycle of Blumeriella jaapii infecting stone-fruit. Acta Phytopathologica Academica Scientia Hungarica, 1: 93-100.

Keitt, G. W. (1918): Inoculation experiments with species of Coccomyces form stone fruit. Journal of Agricultural Research 13: 539-569. 
Keitt, G. W., Blodgett, E. C., Wilson, E. E. \& Magie, R. O. (1937): The epidemiology and control of cherry leaf spot. Univ. Wisc. Agric. Exp. Stn. Res. Bull., 132.

Király, K. \& Szentpéteri, T. (2006): Blumeriella jaapii /Rehm/ v. /Arx/ infection of some sweet cherry cultivars in two years with different precipitation conditions. International Journal of Horticultural Sciences, 12 (3): 47-49.

Nyéki, J., Soltész, M. \& Szabó, Z. (2008): Morphology, biology and fertility of flowers in temperate zone fruits. Akadémiai Kiadó Budapest, pp 450

Ma, Z., Proffer, T. J., Jacobs, J. L. \& Sundin, G. W. (2006): Overexpression of the 14 -demethylase (CYP51) target gene mediates fungicide resistance in Blumeriella jaapii. Applied and Environmental Microbiology, 72: 2581-2585.

MacHardy, W.E. (1996): Apple Scab. Biology, Epidemiology, and Management. APS Press, St. Paul, MN, USA

McManus, P. S., Proffer, T. J., Berardi, R., Gruber, B. R., Nugent, J. E., Ehret, G. R., Ma, Z. \& Sundin, G. W. (2007): Integration of copper-based and reduced-risk fungicides for control of Blumeriella jaapii on sour cherry. Plant Disease, 91: 294-300.

McManus, P. \& Weidman, R. (2001): Evaluation of fungicides for control of sour cherry diseases in Wisconsin, 2000. Fungicide and Nematicide Tests (online) Report 56:STF1. DOI: 10.1094/FN56. The American Phytopathological Society, St. Paul, MN

McManus, P., Sundin, G., Proffer, T., Berardi, R., Ma, Z. \& Ehret, G. (2005): Integration of copper, strobilurin, and sterol demethylation inhibitor fungicides for control of cherry leaf spot. (Abstr.) Phytopathology, 95: S68.

Pedersen, H. L. \& Lrschenkohl L. (1997): Implementation of a warning system to control cherry leaf spot (Blumeriella jaapii) under European conditions. Gartenbauwissenschaft, 62: 197-201.

Pedersen, H. L. \& Hockenhull, J. (1996): Effects of urea on the formation of apothecia and winter conidia of Blumeriella jaapii (cherry leaf spot) and associated microfungi on overwintered cherry leaves. Gartenbauwissenschaft, 61: 257-261.

Proffer, T. J., Berardi, R., Ma, Z., Nugent, J. E., Ehret, G. R., McManus, P. S., Jones, A. L. \& Sundin, G. W. (2006): Occurrence, distribution, and PCR-based detection of resistance to sterol demethylation-inhibiting fungicides in populations of Blumeriella jaapii in Michigan. Phytopathology, 96: 709-717.

Rozsnyai, Zs. \& Apostol, J. (2005): Breeding for sweet and sour cherry disease resistance in Hungary. Acta Horticulturae, 667: $117-122$.

Schmidt, H. \& Gruppe, W. (1988): Breeding dwarfing rootstocks for sweet cherries. HortScience, 23: 112-114.

Schuster M. \& Wolfram, B. (2005): Sour cherry breeding at Dresden-Pillnitz. Acta Horticulturae, 667: 127-130.

Sjulin, T. M:, Jones A. L. \& Andersen, R. L. (1989): Expression of partial resitance to cherry leaf spot in cultivars of sweet, sour, duke, and European ground cherry. Plant Disease, 73: 56-61.

Sundin, G. W., Ehret, G. R., McManus, P. S., Nugent, J. E., Klein, W. M., Anderson, M. D. \& Proffer, T. J. (2005): Evaluation of new fungicide rotations for cherry leaf spot control on Montmorency tart cherries in NW Michigan, 2004. Fungicide and Nematicide Tests (online) Report 60:STF004. DOI: 10.1094/FN60. The American Phytopathological Society, St. Paul, MN

Sundin, G. W., Ehret, G. R., McManus, P. S., Nugent, J. E., Klein, W. M., Anderson, M. D. \& Proffer, T. J. (2005): Evaluation of new fungicide rotations for cherry leaf spot control on Montmorency tart cherries in NW Michigan, 2004. Fungic. Nematicide Tests, 60: STF004.

Ware, G. W. \& Whitacre, D. M. (2004): Fungicides and bactericides. Pages 155-172 in: The Pesticide Book, 6th ed. MeisterPro Information Resources, Willoughby, $\mathrm{OH}$.

Wharton, P., Iezzoni, A. \& Jones, A. (2003): Screening cherry germ plasm for resistance to leaf spot. Plant Disease, 87: 471-477. 